\title{
Analysis of Variation in cis-9, trans-11 Conjugated Linoleic Acid (CLA) in Milk Fat of Dairy Cows ${ }^{1}$
}

\author{
D. G. Peterson, J. A. Kelsey, and D. E. Bauman \\ Department of Animal Science \\ Cornell University \\ Ithaca, NY 14853
}

\section{ABSTRACT}

Conjugated linoleic acid (CLA) is a fatty acid with numerous putative health benefits and is a natural component of ruminant-derived food products. An intermediate in rumen biohydrogenation is cis-9, trans-11 CLA, the major CLA isomer in milk fat. However, the major source of cis-9, trans-11 CLA in milk is endogenous synthesis by $\Delta^{9}$-desaturase conversion of trans- $11 \mathrm{C}_{18: 1}$, another rumen biohydrogenation intermediate. The desaturase indices serve as a proxy for $\Delta^{9}$-desaturase activity and are calculated from the ratios of fatty acid pairs that represent product/substrate for this enzyme. This study analyzed individual animal variation in milk fat content of cis-9, trans-11 CLA and in desaturase indices in milk fat. Thirty lactating Holstein cows were allocated to one of three treatment groups: one received a standard total mixed ration, one received a diet that produced an elevated milk fat content of CLA, and a third treatment group was alternated between these diets at 3 -wk intervals over the 12 -wk study. There was a two- to threefold variation among individuals on the same diet for both milk fat content of CLA and desaturase indices in milk fat. This hierarchy was maintained to a large extent over the 12 -wk study even in the variable treatment group that alternated between the two diets. Within the variable diet treatment, some animals consistently had a substantial response in milk fat content of CLA to dietary shifts, whereas other cows had little or no response. We conclude that while diet is a major determinant of the CLA content in milk fat, individual animal differences also have a substantial effect. The variation among individuals includes differences related to both rumen biohydrogenation and $\Delta^{9}$ desaturase activity in the mammary gland.

(Key words: conjugated linoleic acid, milk fat, $\Delta^{9}$-desaturase, variation)

Received November 8, 2001.

Accepted March 8, 2002.

Corresponding author: D. E. Bauman; e-mail: deb6@cornell.edu.

${ }^{1}$ Supported in part by Land O' Lakes, Inc. (St. Paul, MN), Northeast Dairy Foods Research Center and Cornell Agricultural Experiment Station.
Abbreviation key: CLA = conjugated linoleic acid, ED = extruded full-fat soybean diet treatment, $\mathbf{S D}=$ standard diet treatment, $\mathbf{V D}_{\mathbf{E}}=$ variable diet treatment when receiving the $\mathrm{ED}$ treatment diet, $\mathbf{V D}_{\mathbf{S}}=$ variable diet treatment when receiving the SD treatment diet.

\section{INTRODUCTION}

Conjugated linoleic acid (CLA) is a mixture of positional and geometric isomers of octadecadienoic acid with conjugated double bonds. Biomedical studies with animal models have demonstrated a variety of beneficial health effects from CLA, including anticarcinogenic, antiatherogenic, antiobesity, immune system enhancement and antidiabetic (McGuire and McGuire, 2000; Whigham et al., 2000; Pariza et al., 2001). The various health effects of CLA may relate to specific CLA isomers, and this is an active area of research. However, it has been established that the cis-9, trans-11 CLA is anticarcinogenic when included in the diet as a natural component of food (Ip et al., 1999), and cis-9, trans-11 $\mathrm{C}_{18: 2}$ is the major CLA isomer in dairy products (Parodi, 1997). The major source of cis-9, trans-11 CLA in milk fat is endogenous synthesis by $\Delta^{9}$-desaturase with the precursor being trans-11 $\mathrm{C}_{18: 1}$, an intermediate formed in rumen biohydrogenation of polyunsaturated fatty acids (Griinari et al., 2000; Corl et al., 2001). CLA is also an intermediate in rumen biohydrogenation, and a portion is absorbed and provides the remainder of the CLA in milk fat (Bauman et al., 2000b). In addition to endogenous synthesis of cis-9, trans-11 CLA, $\Delta^{9}$-desaturase catalyzes the introduction of a cis-9 double bond in several other fatty acids found in milk fat. Ratios for the pairs of fatty acids that represent product/substrate relationships are a proxy for $\Delta^{9}$-desaturase activity (Bauman et al., 2001).

Factors affecting the milk fat content of CLA have been reviewed, and diet plays a major role (Griinari and Bauman, 1999; Bauman et al., 2001). However, previous investigations have observed substantial variation in milk fat content of CLA among individual cows fed the same diet (Jiang et al., 1996; Kelly et al., 1998a; 1998b; Lawless et al., 1998). An analysis of this varia- 
Table 1. Nutrient composition of experimental diets.

\begin{tabular}{lcc}
\hline & \multicolumn{2}{c}{ Treatment diets $^{1}$} \\
\cline { 2 - 3 } Composition & SD & ED \\
\hline Ingredients, \% of DM & & \\
Corn silage & 42.6 & 40.7 \\
Alfalfa silage & 25.5 & 23.1 \\
High moisture corn & 12.8 & 12.1 \\
Soybean meal & 6.4 & 5.5 \\
Soy plus & 6.9 & 0 \\
ESB & 0 & 13.4 \\
Dicalcium phosphate & 0.2 & 0.2 \\
Limestone & 0.2 & 0.2 \\
Mineral and vitamin mix & 0.1 & 0.1 \\
Sodium bicarbonate & 0.6 & 0.6 \\
Brome hay & 4.7 & 4.1 \\
Chemical, \% of DM & & \\
CP & 17.7 & 17.8 \\
NDF & 36.7 & 35.0 \\
ADF & 20.2 & 21.4 \\
DM, \% of diet & 44.5 & 46.0 \\
NE & 1.6 \\
\hline
\end{tabular}

${ }^{1} \mathrm{SD}=$ Standard TMR diet and ED = diet containing extruded fullfat soybeans.

${ }^{2} \mathrm{ESB}=$ Extruded full-fat soybeans.

tion was the focus of the present study. One objective was to examine the hierarchy of individual cows over time in the milk fat content of CLA. Given the importance of endogenous synthesis of CLA, a second objective was to examine the individual hierarchy in the milk fat ratios for fatty acid pairs related to $\Delta^{9}$-desaturase activity. We examined these hierarchies over a 12 -wk period for three treatment groups, one fed a diet that resulted in a typical milk fat content of CLA, one fed a diet that resulted in an elevated milk fat content of CLA, and a third treatment group that was switched back and forth between the two diets at 3-wk intervals.

\section{MATERIALS AND METHODS}

\section{Animals and Treatments}

All procedures involving dairy cows were approved by the Cornell University Institutional Animal Care and Use Committee. Thirty lactating Holstein cows were blocked according to parity (9 multiparous, 21 primiparous) and DIM (96.4 \pm 2.3 ; mean $\pm \mathrm{SE})$ and randomly allocated to one of three treatments. Cows were housed in group pens by treatment at the Cornell University Teaching and Research Center (Harford, NY).

Treatments involved feeding diets that were formulated to give differences in the milk fat content of CLA (Table 1). The first treatment group received a traditional corn-based TMR for the duration of the 12-wk study; this diet would produce a standard milk fat content of CLA (SD treatment). The second group received a diet that included extruded full-fat soybeans for the 12 -wk period; this diet would result in an elevated milk fat content of CLA (ED treatment). The third group (variable diet; VD treatment) was alternated between the two diets at 3 -wk intervals (four periods) so that during periods 1 and 3 they were fed the standard diet $\left(\mathbf{V D}_{\mathbf{S}}\right)$ and during periods 2 and 4, the extruded full-fat soybean $\operatorname{diet}\left(\mathbf{V D}_{\mathbf{E}}\right)$.

Diets were formulated using the Cornell Net Carbohydrate and Protein System (Fox et al., 1992) to meet or exceed nutrient requirements (NRC, 1989). Cows were fed ad libitum, with fresh feed given once daily, and they had free access to water. For analyses, feed samples were taken once per week directly after feeding and dried at $50^{\circ} \mathrm{C}$ for $72 \mathrm{~h}$ for DM determination. Samples were composited at 4-wk intervals for analysis of composition by wet chemistry methods (Dairy One Cooperative, Inc., Ithaca, NY).

Cows were milked 3 times per day. Milk yield was recorded daily and duplicate samples collected from each milking $1 \mathrm{~d} / \mathrm{wk}$. One set was analyzed for fat and protein by infrared analysis (Dairy One Cooperative, Inc.). The second set of milk samples was combined based on milk yield to obtain an individual cow's weekly composite sample that was analyzed for fatty acid composition.

\section{Fatty Acid Analysis}

Composited milk samples were centrifuged at 17,800 $\times g$ for $30 \mathrm{~min}$ at $8^{\circ} \mathrm{C}$, and 300 to $400 \mathrm{mg}$ of fat cake was removed for extraction and methylation. Lipid extraction was performed by the method of Hara and Radin (1978) and methyl esters of the fatty acids were prepared by transesterification with sodium methoxide according to the method of Christie (1982) as detailed by Chouinard et al. (1999). Fatty acid methyl esters were quantified by gas chromatography using a SP2560 capillary column $(100 \mathrm{~m} \times 0.25 \mathrm{~mm}$ i.d. with 0.2 $\mu \mathrm{m}$ film thickness; Supelco Inc., Bellefonte, PA). The analysis involved a programmed run with temperature ramps. The oven temperature was initially $50^{\circ} \mathrm{C}$ for 1 min then ramped to $160^{\circ} \mathrm{C}$ at $5^{\circ} \mathrm{C} / \mathrm{min}$ and held for 42 min. The temperature was then ramped again at $5^{\circ} \mathrm{C} / \mathrm{min}$ to $190^{\circ} \mathrm{C}$ and held for $22 \mathrm{~min}$. Injector and detector temperatures were maintained at $250^{\circ} \mathrm{C}$. The flow rate for hydrogen carrier gas was $1 \mathrm{ml} / \mathrm{min}$. Hydrogen flow to the detector was $25 \mathrm{ml} / \mathrm{min}$, air flow was $400 \mathrm{ml} / \mathrm{min}$, and the nitrogen make-up gas flow was 45 $\mathrm{ml} / \mathrm{min}$.

Each peak was identified and quantified using pure methyl ester samples (Nu Chek Prep, Elysian, MN). A butter reference standard (CRM 164; Commission of the European Communities, Community Bureau of Ref- 
Table 2. Effect of treatment on milk production. ${ }^{1}$

\begin{tabular}{|c|c|c|c|c|c|}
\hline \multirow[b]{2}{*}{ Variable } & \multicolumn{4}{|c|}{ Treatments $^{2}$} & \multirow[b]{2}{*}{$P^{3}$} \\
\hline & SD & ED & $\mathrm{VD}_{\mathrm{S}}$ & $\mathrm{VD}_{\mathrm{E}}$ & \\
\hline $\begin{array}{l}\text { Milk yield, } \mathrm{kg} / \mathrm{d} \\
\text { Milk protein }\end{array}$ & $35.5 \pm 1.1^{\mathrm{ab}}$ & $37.3 \pm 1.1^{\mathrm{a}}$ & $32.9 \pm 1.2^{\mathrm{b}}$ & $32.7 \pm 1.2^{\mathrm{b}}$ & 0.03 \\
\hline$\%$ & $2.75 \pm 0.05$ & $2.79 \pm 0.05$ & $2.84 \pm 0.05$ & $2.83 \pm 0.06$ & 0.66 \\
\hline $\begin{array}{l}\mathrm{kg} / \mathrm{d} \\
\text { Milk fat }\end{array}$ & $0.97 \pm 0.03^{\mathrm{ab}}$ & $1.05 \pm 0.03^{\mathrm{a}}$ & $0.91 \pm 0.03^{\mathrm{b}}$ & $0.87 \pm 0.04^{b}$ & 0.01 \\
\hline $\begin{array}{l}\% \\
\mathrm{~kg} / \mathrm{d}\end{array}$ & $\begin{array}{l}3.33 \pm 0.11 \\
1.20 \pm 0.05\end{array}$ & $\begin{array}{l}3.09 \pm 0.11 \\
1.12 \pm 0.05\end{array}$ & $\begin{array}{l}3.43 \pm 0.11 \\
1.14 \pm 0.05\end{array}$ & $\begin{array}{l}3.49 \pm 0.13 \\
1.09 \pm 0.06\end{array}$ & $\begin{array}{l}0.13 \\
0.21\end{array}$ \\
\hline
\end{tabular}

${ }^{1}$ Each treatment had 10 cows and values are mean $\pm \mathrm{SE}$ for $12 \mathrm{wk}(\mathrm{SD}$ and $\mathrm{ED})$ or $6 \mathrm{wk}\left(\mathrm{VD}_{\mathrm{S}}\right.$ and $\mathrm{VD}_{\mathrm{E}}$ ). ${ }^{2} \mathrm{SD}=$ Standard diet treatment, $\mathrm{ED}=$ extruded full-fat soybean diet treatment, $\mathrm{VD}_{\mathrm{S}}=$ variable diet treatment on the standard diet, and $\mathrm{VD}_{\mathrm{E}}=$ variable diet treatment on the extruded full-fat soybean diet.

${ }^{3}$ When a treatment effect was significant $(P<0.05)$, differences among treatments were compared by $t$ test as indicated by superscripts within a row (a, b; $P<0.05)$.

erence, Brussels, Belgium) was used to determine recoveries and correction factors for individual fatty acids. The butter reference standard was also used at regular intervals throughout the analysis as an aid in quality control.

\section{Statistical Analyses}

Performance and fatty acid data were analyzed as an unbalanced repeated measures design using the PROC MIXED procedure of SAS (2000) according to the model:

$$
\mathrm{Y}_{\mathrm{ijk}}=\mu+\mathrm{D}_{\mathrm{i}}+\mathrm{P}_{\mathrm{j}}+\mathrm{C}_{\mathrm{k}}+\varepsilon_{\mathrm{ijk}},
$$

where $\mathrm{Y}$ is the response variable, $\mu$ is the overall mean, $D_{i}$ is the dietary treatment, $P_{j}$ is the period effect, $C_{k}$ is the cow effect (treated as a random factor), and $\varepsilon_{\mathrm{ijk}}$ is the residual error term. The effect of treatment was analyzed as a fixed effect in a mixed ANOVA model, with cow effects treated as a random factor. If the overall $\mathrm{F}$-test of treatment was significant $(P<0.05)$, then a Fisher's $t$-test was performed to discern differences among the treatments ("Ismeans/pdiff" command in SAS). A term was initially included in the model for period $\times$ diet interaction, but it was not significant and was dropped from the final model. The PROC REG function of SAS was used to compute the regression equation and correlation coefficient between trans-11 $\mathrm{C}_{18: 1}$ and cis-9, trans-11 CLA. Correlation of ratios for the fatty acid pairs that are proxies for $\Delta^{9}$-desaturase was determined using the PROC CORR procedure of SAS.

\section{RESULTS}

Cows were grouped by treatment ( $\mathrm{n}=10 \mathrm{cows} /$ treatment) and DMI (kg/d) averaged $185 \pm 3,181 \pm 3,182$ \pm 4 , and $191 \pm 4$ (mean $\pm \mathrm{SE}$ ) for $\mathrm{SD}, \mathrm{ED}, \mathrm{VD}_{\mathrm{S}}$ and $\mathrm{VD}_{\mathrm{E}}$, respectively. Milk production and milk composition are reported in Table 2. Milk fat percent and milk fat yield were similar among treatment groups. Cows on the ED treatment exhibited higher milk production and a slightly greater milk protein yield, although milk protein percent was not affected by diet.

Fatty acid composition of the milk fat is presented in Table 3. Cows consuming the extruded full-fat soybean diet exhibited a greater proportion of long-chain ( $\geq 18$ carbon) fatty acids with major increases occurring for stearic acid, oleic acid and linoleic acid. In contrast, cows fed the standard corn-based TMR diet produced milk fat with a greater proportion of short and medium chain fatty acids and an increased content of palmitic acid.

Milk fat content of $c i s-9$, trans-11 CLA was successfully elevated by the ED treatment (Table 3), and the elevated level was maintained for the duration of the 12-wk study (Figure 1). Alternating the diet for the VD treatment group resulted in rapid shifts in the CLA content in milk fat that matched the cis-9, trans-11 CLA content of the SD and ED treatment groups in corresponding periods (Figure 1).

Figure 2 presents the cis-9, trans-11 CLA concentrations in milk fat for individual cows on the study averaged over each 3 -wk period. There was a two- to threefold range in CLA concentration among individuals regardless of diet. The VD treatment group that was switched between the two diets also exhibited the same two- to threefold range. Individuals in all three treatments were quite consistent in their position in the hierarchy of cis-9, trans-11 CLA concentration in milk fat across all four periods.

Trans- $11 \mathrm{C}_{18: 1}$ and cis-9, trans-11 CLA represent a precursor-product relationship for endogenous synthesis via $\Delta^{9}$-desaturase, and the correlation between them was 0.61 across all cows and treatments (Figure 3 ). The ratio of cis-9, trans-11 CLA to trans-11 18:1 has been referred to as the desaturase index (Choi et al., 2000), and there are three additional fatty acid pairs in milk fat that also reflect this relationship for $\Delta^{9}$-desaturase, 
Table 3. Effect of treatment on fatty acid composition of milk fat. ${ }^{1}$

\begin{tabular}{|c|c|c|c|c|c|}
\hline \multirow[b]{2}{*}{ Fatty acid } & \multicolumn{4}{|c|}{ Treatments $^{2}$} & \multirow[b]{2}{*}{$P^{3}$} \\
\hline & SD & ED & $\mathrm{VD}_{\mathrm{S}}$ & $\mathrm{VD}_{\mathrm{E}}$ & \\
\hline & \multicolumn{4}{|c|}{$\mathrm{g} / 100 \mathrm{~g}$ of fatty acids } & \\
\hline $\mathrm{C}_{4: 0}$ & $5.96 \pm 0.12$ & $5.66 \pm 0.12$ & $5.64 \pm 0.12$ & $5.73 \pm 0.15$ & 0.18 \\
\hline $\mathrm{C}_{6: 0}$ & $2.77 \pm 0.08^{a}$ & $2.48 \pm 0.07^{\mathrm{b}}$ & $2.80 \pm 0.08^{\mathrm{a}}$ & $2.70 \pm 0.09^{a}$ & 0.001 \\
\hline $\mathrm{C}_{8: 0}$ & $1.29 \pm 0.04^{\mathrm{ac}}$ & $1.04 \pm 0.04^{\mathrm{b}}$ & $1.31 \pm 0.04^{\mathrm{a}}$ & $1.19 \pm 0.05^{\mathrm{c}}$ & 0.001 \\
\hline $\mathrm{C}_{10: 0}$ & $2.52 \pm 0.12^{\mathrm{ab}}$ & $2.21 \pm 0.12^{\mathrm{a}}$ & $2.74 \pm 0.12^{\mathrm{b}}$ & $2.31 \pm 0.13^{\mathrm{a}}$ & 0.001 \\
\hline $\mathrm{C}_{12: 0}$ & $2.85 \pm 0.12^{\mathrm{a}}$ & $2.48 \pm 0.12^{\mathrm{b}}$ & $2.99 \pm 0.12^{\mathrm{a}}$ & $2.45 \pm 0.12^{\mathrm{b}}$ & 0.001 \\
\hline $\mathrm{C}_{14: 0}$ & $10.51 \pm 0.23^{\mathrm{a}}$ & $9.05 \pm 0.23^{\mathrm{b}}$ & $10.48 \pm 0.24^{\mathrm{a}}$ & $9.07 \pm 0.24^{\mathrm{b}}$ & 0.001 \\
\hline c9 $\mathrm{C}_{14: 1}$ & $0.94 \pm 0.05^{\mathrm{a}}$ & $0.76 \pm 0.05^{\mathrm{bc}}$ & $0.87 \pm 0.06^{\mathrm{ac}}$ & $0.75 \pm 0.04^{b}$ & 0.001 \\
\hline $\mathrm{C}_{16: 0}$ & $30.81 \pm 0.83^{\mathrm{a}}$ & $24.54 \pm 0.83^{\mathrm{b}}$ & $28.60 \pm 0.89^{\mathrm{a}}$ & $23.96 \pm 0.83^{b}$ & 0.001 \\
\hline c9 $\mathrm{C}_{16: 1}$ & $1.60 \pm 0.07^{\mathrm{a}}$ & $1.34 \pm 0.07^{\mathrm{b}}$ & $1.57 \pm 0.08^{\mathrm{a}}$ & $1.26 \pm 0.08^{b}$ & 0.001 \\
\hline $\mathrm{C}_{18: 0}$ & $9.93 \pm 0.41^{\mathrm{a}}$ & $11.82 \pm 0.41^{\mathrm{bc}}$ & $10.93 \pm 0.41^{\mathrm{ac}}$ & $12.44 \pm 0.41^{\mathrm{a}}$ & 0.001 \\
\hline t6 to t8 $\mathrm{C}_{18: 1}$ & $0.32 \pm 0.02^{\mathrm{a}}$ & $0.54 \pm 0.02^{b}$ & $0.36 \pm 0.03^{\mathrm{a}}$ & $0.52 \pm 0.03^{b}$ & 0.001 \\
\hline t9 $C_{18: 1}$ & $0.25 \pm 0.02^{\mathrm{a}}$ & $0.44 \pm 0.02^{\mathrm{b}}$ & $0.29 \pm 0.02^{\mathrm{a}}$ & $0.45 \pm 0.02^{\mathrm{b}}$ & 0.001 \\
\hline $\mathrm{t} 10 \mathrm{C}_{18: 1}$ & $0.62 \pm 0.13^{\mathrm{a}}$ & $0.96 \pm 0.13^{b}$ & $0.71 \pm 0.13^{\mathrm{a}}$ & $1.08 \pm 0.14^{\mathrm{b}}$ & 0.001 \\
\hline t11 $\mathrm{C}_{18: 1}$ & $1.03 \pm 0.10^{\mathrm{a}}$ & $1.75 \pm 0.10^{\mathrm{b}}$ & $1.12 \pm 0.10^{\mathrm{a}}$ & $2.18 \pm 0.11^{\mathrm{c}}$ & 0.001 \\
\hline c9 $\mathrm{C}_{18: 1}$ & $21.39 \pm 0.76^{\mathrm{a}}$ & $25.11 \pm 0.76^{\mathrm{b}}$ & $22.69 \pm 0.76^{\mathrm{a}}$ & $25.50 \pm 0.80^{b}$ & 0.001 \\
\hline c9, c12 $\mathrm{C}_{18: 2}$ & $2.50 \pm 0.12^{\mathrm{a}}$ & $4.27 \pm 0.12^{\mathrm{b}}$ & $2.56 \pm 0.12^{\mathrm{a}}$ & $3.20 \pm 0.14^{\mathrm{c}}$ & 0.001 \\
\hline $\mathrm{c} 9, \mathrm{c} 12, \mathrm{c} 15 \mathrm{C}_{18: 3}$ & $0.49 \pm 0.02^{\mathrm{a}}$ & $0.63 \pm 0.01^{\mathrm{b}}$ & $0.45 \pm 0.02^{\mathrm{a}}$ & $0.56 \pm 0.02^{\mathrm{c}}$ & 0.001 \\
\hline c9, t11 CLA & $0.51 \pm 0.03^{\mathrm{a}}$ & $0.80 \pm 0.03^{b}$ & $0.52 \pm 0.03^{\mathrm{a}}$ & $0.87 \pm 0.04^{\mathrm{b}}$ & 0.001 \\
\hline others & $3.41 \pm 0.09^{\mathrm{a}}$ & $3.94 \pm 0.09^{b}$ & $3.61 \pm 0.13^{\mathrm{a}}$ & $3.97 \pm 0.13^{b}$ & 0.001 \\
\hline
\end{tabular}

${ }^{1}$ Each treatment had 10 cows and values are mean \pm SE for $12 \mathrm{wk}$ (SD and ED) or $6 \mathrm{wk}$ (VDS and VDE).

${ }^{2} \mathrm{SD}=$ Standard diet treatment, $\mathrm{ED}=$ extruded full-fat soybean diet treatment, $\mathrm{VD}_{\mathrm{S}}=$ variable diet treatment on the standard diet and $\mathrm{VD}_{\mathrm{E}}=$ Variable diet treatment on the extruded full-fat soybean diet.

${ }^{3}$ When a treatment effect was significant $(P<0.05)$, differences among treatments were compared by $t$ test as indicated by superscripts within a row (a, b, c; $P<0.05)$.

cis-9 $\mathrm{C}_{14: 1} / \mathrm{C}_{14: 0}$, cis- $9 \mathrm{C}_{16: 1} / \mathrm{C}_{16: 0}$, and cis- $9 \mathrm{C}_{18: 1} / \mathrm{C}_{18: 0}$. The effect of treatment was compared for all four desaturase indices (Table 4). The ratio of cis-9, trans-11 CLA/trans$11 \mathrm{C}_{18: 1}$ was lower for cows fed the diet containing extruded full-fat soybeans, but there were no treatment differences for the ratios of other fatty acid pairs.

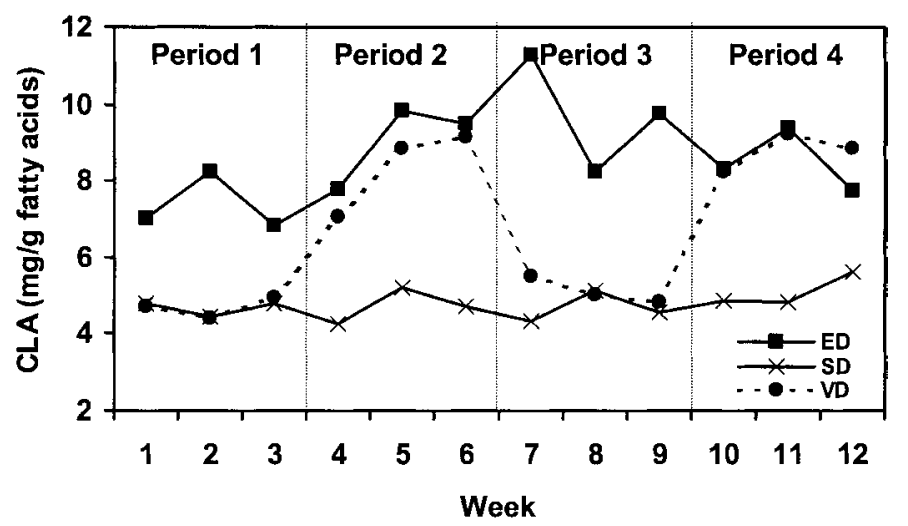

Figure 1. Weekly treatment averages in milk fat content of cis9, trans-11 conjugated linoleic acid (CLA). Treatment groups ( $\mathrm{n}=10$ cows per treatment) included cows receiving a standard TMR diet (SD treatment), a diet including extruded full-fat soybeans (ED treatment), and a variable diet group (VD treatment) that alternated between diets at 3 -wk intervals so that they received the SD treatment diet during periods 1 and 3, and the ED treatment diet during periods 2 and 4 . Pooled $\mathrm{SE}=0.49 \mathrm{mg} / \mathrm{g}$ fatty acids.
The temporal pattern of the desaturase indices for individual cows was examined and values for $c i s-9 \mathrm{C}_{14: 1} /$ $\mathrm{C}_{14: 0}$ and cis-9, trans-11 CLA/ trans- $11 \mathrm{C}_{18: 1}$ are presented in Figure 4. The range among individuals on the same treatment was about twofold. Individual cows on the SD and ED treatments showed a remarkable degree of consistency over the 12-wk experimental period in their position in the desaturase index hierarchy relative to other members of their treatment group. A consistent hierarchy was also maintained for the VD treatment group across dietary shifts (Figure 4). The range among individuals and the consistency over time were similar for the ratios of cis- $9 \mathrm{C}_{16: 1} / \mathrm{C}_{16: 0}$ and cis-9 $\mathrm{C}_{18: 1} / \mathrm{C}_{18: 0}$ (data not presented). There was also good agreement among the pairs of fatty acids related to $\Delta^{9}$ desaturase irrespective of diet. The correlation coefficients between ratios for the fatty acid pairs in the desaturase index ranged from 0.48 to 0.78 (Table 5) demonstrating the positive relationship among all the indices.

\section{DISCUSSION}

Conjugated linoleic acids have been shown to have a wide array of health benefits in studies with animal disease and cancer models (Whigham et al., 2000; Pariza et al., 2001). Dairy products accounted for approximately $60 \%$ of the CLA intake in US diets (Ritzenhaler 

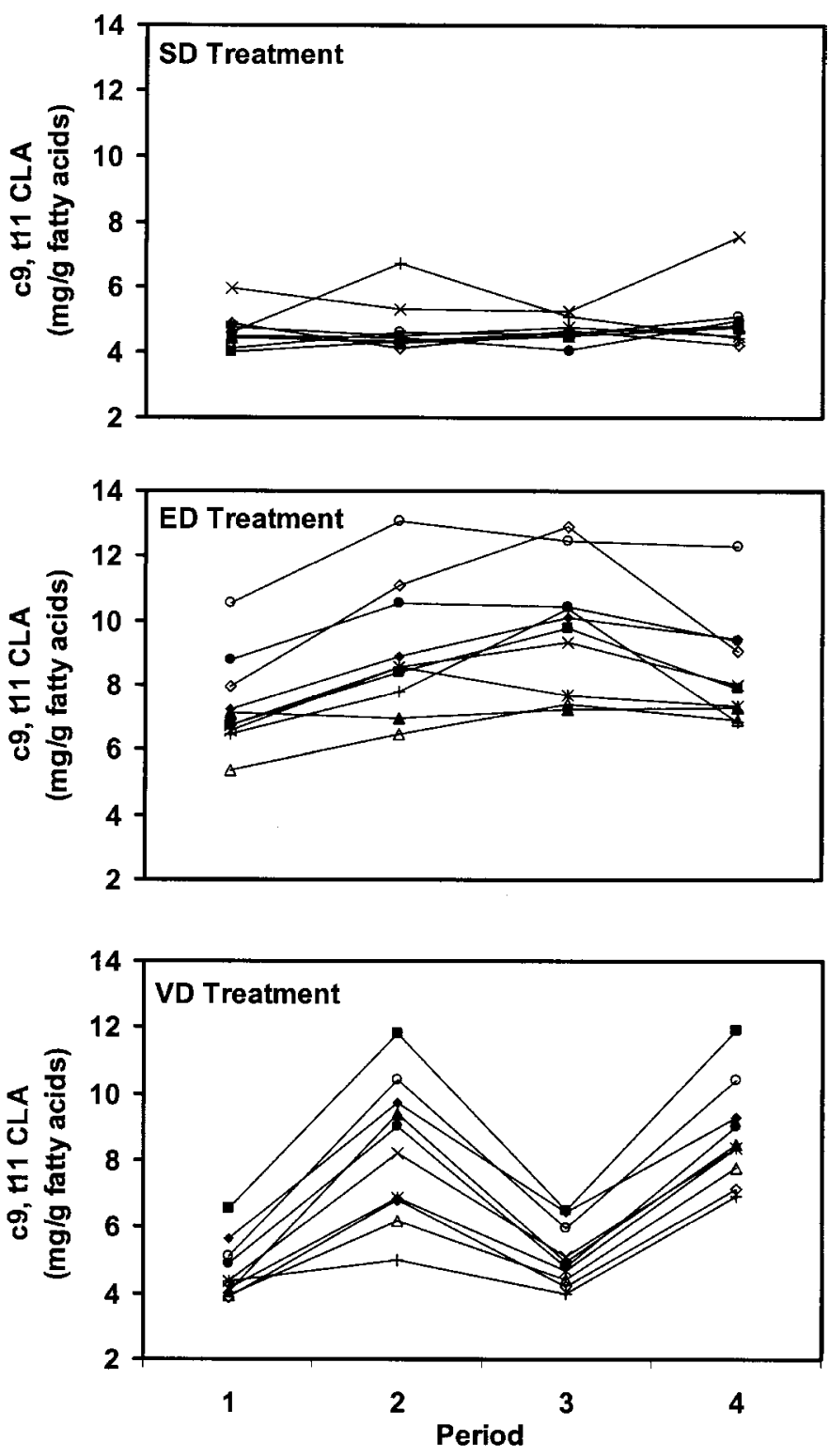

Figure 2. Milk fat content of cis-9, trans-11 CLA for individual cows on each treatment. Treatment groups included cows receiving a standard TMR diet (SD treatment), a diet including extruded fullfat soybeans (ED treatment), and a variable diet group (VD treatment) that alternated between diets at 3 -wk intervals so that they received the SD treatment diet during periods 1 and 3 , and the ED treatment diet during periods 2 and 4 . Each symbol represents an individual cow ( $\mathrm{n}=10$ cows per treatment) and each period value represents the mean of the three weekly values for that period. SE for individual period means averaged $0.035,0.035$, and $0.040 \mathrm{mg} / \mathrm{g}$ fatty acids for SD, ED and VD, respectively.

et al., 2001), and detailed analysis of milk fat has identified 19 different isomers of CLA (Sehat et al., 1998). However, the predominant CLA isomer is cis-9, trans11 , and it generally accounts for 75 to $90 \%$ of the total CLA present in milk fat (Sehat et al., 1998; Bauman

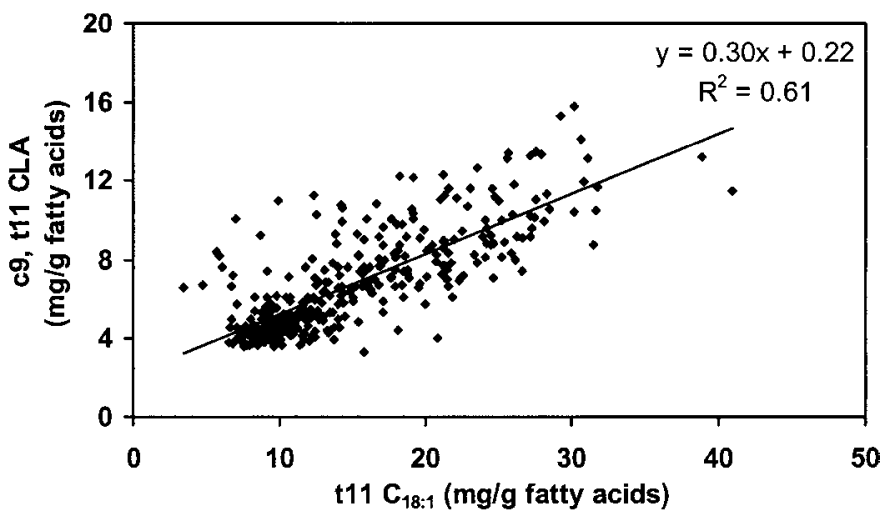

Figure 3. Regression of the milk fat content of cis-9, trans-11 CLA on trans-11 $\mathrm{C}_{18: 1}$ for all cows $(\mathrm{n}=30)$ over the 12 -wk study. Each point represents a weekly value for an individual cow. $P<0.001$.

et. al., 2000a). Diet of the cow has a major influence on the milk fat content of CLA, and these effects have been recently summarized (Bauman et al., 2000b, 2001). Polyunsaturated lipids are one important component, and in the present study extruded full-fat soybeans were fed as a slow-release source of linoleic acid. Across treatment groups we observed an increase in the milk fat content of cis-9, trans-11 CLA when cows consumed the diet containing extruded full-fat soybeans compared with cows fed the standard corn-based TMR (8.3 vs. 5.0 $\mathrm{mg}$ of $\mathrm{CLA} / \mathrm{g}$ of fatty acids; $P<0.0001$ ). Others have reported increases in milk fat content of CLA of similar or greater magnitude when extruded full-fat soybeans were fed (Lawless et al., 1998; Dhiman et. al., 1999; Solomon et al., 2000; Chouinard et al., 2001)

One objective was to examine the variation in milk fat content of CLA in individual cows over time and across different dietary treatments. Data demonstrated that average cis-9, trans-11 CLA content of milk fat for the ED and SD treatments was relatively constant over the 12-wk experimental period. The VD treatment group had a milk fat content of CLA similar to the SD and ED treatments during each period that they were receiving the same respective diet (Figure 1). On an individual cow basis, we observed a two- to threefold range in the milk fat content of CLA for each of the treatment groups (Figure 2). Previous studies involving diets ranging from TMR to pasture reported a similar two- to threefold range in milk fat content of CLA for individual cows (Jiang et al., 1996; Kelly et al., 1998a, 1998b; Lawless et. al., 1998; Solomon et al., 2000; White et al., 2001).

White et al. (2001) recently reported that individual cows maintained a relatively constant milk fat content of CLA over a 4 -wk period. In the present study, comparison of the temporal pattern of milk fat content of cis- 
Table 4. Effect of diet on milk fatty acid pairs in the desaturase index.

\begin{tabular}{lllll}
\hline & \multicolumn{2}{c}{ Treatments $^{1,2}$} & & \\
\cline { 2 - 3 } Fatty acid pair & $\mathrm{SD}+\mathrm{VD}_{\mathrm{S}}$ & $\mathrm{ED}+\mathrm{VD}_{\mathrm{E}}$ & $\mathrm{SEM}$ & $P$ \\
\hline c9, t11CLA/t11 $\mathrm{C}_{18: 1}$ & $0.52^{\mathrm{a}}$ & $0.44^{\mathrm{b}}$ & 0.02 & 0.01 \\
c9 $\mathrm{C}_{14: 1} / \mathrm{C}_{14: 0}$ & 0.088 & 0.084 & 0.003 & 0.11 \\
c9 $\mathrm{C}_{16: 1} / \mathrm{C}_{16: 0}$ & 0.054 & 0.053 & 0.001 & 0.38 \\
c9 $\mathrm{C}_{18: 1} / \mathrm{C}_{18: 0}$ & 2.19 & 2.11 & 0.07 & 0.15 \\
\hline
\end{tabular}

${ }^{1} \mathrm{SD}=$ Standard diet treatment, $\mathrm{VD}_{\mathrm{S}}=$ variable diet treatment on the standard diet, $\mathrm{ED}=$ extruded fullfat soybean diet and $\mathrm{VD}_{\mathrm{E}}=$ variable diet treatment on the extruded full-fat soybean diet.

${ }^{2}$ Treatments groups have been combined by diet and represent mean of all cows for all weeks on a given $\operatorname{diet}\left(12 \mathrm{wk}\right.$ for SD and $6 \mathrm{wk}$ for $\mathrm{VD}_{\mathrm{S}} ; 12 \mathrm{wk}$ for $\mathrm{ED}$ and $6 \mathrm{wk}$ for $\mathrm{VD}_{\mathrm{E}}$ ).

9, trans-11 CLA over the 12-wk period indicated that the individual hierarchy in CLA levels was maintained to a substantial extent for both SD and ED treatments (Figure 2). Lawless et al. (1999) previously compared CLA content in milk samples obtained from individual cows at approximately 75 and $120 \mathrm{~d}$ postpartum; four breeds were compared, and correlations of 0.17 to 0.56 for the CLA content of the two samples were observed. Particularly revealing in the present study was the VD treatment group in which the hierarchy was maintained even as cows were switched back and forth between the two diets that resulted in very different milk fat concentrations of CLA (Figure 2). Interestingly, some animals in the VD treatment consistently had a substantial response in milk fat cis-9, trans-11 CLA to dietary shifts, whereas other cows had little or no response. This phenomenon was also observed by Kelly et al. (1998b) when animals were shifted from a cornbased TMR to a diet of only pasture. In the present study, cows were similar in milk production and stage of lactation, but they were group fed, so that the effect of intake on the variation in CLA content among individuals cannot be evaluated. Studies have observed that substantial underfeeding caused an increase (Jiang et al., 1996) or a decrease (Stanton et al., 1997) in group averages for CLA content of milk fat. However, variation among individuals was not considered, and we know of no study that has specifically examined the contribution of intake to individual variation in CLA content of milk fat. Based on the consistency of literature values in CLA content of milk fat across studies (see review by Bauman et al., 2001), it seems likely that subtle differences in feed intake among well-fed cows will be of little or no importance in explaining variation among individuals.

The cis-9, trans-11 CLA in milk fat originates from the incomplete biohydrogenation of polyunsaturated fatty acids (Griinari and Bauman, 1999). The majority of milk fat CLA is synthesized endogenously via $\Delta^{9}$ desaturase from trans- $11 \mathrm{C}_{18: 1}$, an intermediate in the rumen biohydrogenation of linoleic and linolenic acids
(Griinari et al., 2000; Corl et al., 2001). The remainder of the CLA in milk fat arises directly from CLA absorbed from the digestive tract after being produced in the rumen as an intermediate in linoleic acid biohydrogenation. Thus, milk fat content of cis-9, trans-11 CLA is dependent on rumen production of trans-11 $\mathrm{C}_{18: 1}$ and CLA, as well as tissue activity of $\Delta^{9}$-desaturase (Bauman et al., 2001).

In the present study, the correlation coefficient was 0.61 between cis-9, trans-11 CLA and trans- $11 \mathrm{C}_{18: 1}$ across all animals and diets $(P<0.01)$. The ratio of cis-9, trans-11 CLA to trans- $11 \mathrm{C}_{18: 1}$ was affected by treatment, averaging 0.52 and 0.44 for the standard diet and the extruded full-fat soybean diet, respectively (Table 4). Other studies have reported milk fat ratios of 0.25 to 0.46 for cis-9, trans-11 CLA/trans- $11 \mathrm{C}_{18: 1}$ under various dietary conditions (Jiang et al., 1996; Jahreis et al., 1997; Lawless et al., 1998; Griinari and Bauman, 1999). The lower ratio of cis-9, trans-11 CLA to trans-11 $\mathrm{C}_{18: 1}$ on the extruded full-fat soybean diet where both substrate and product are present in milk fat at elevated concentrations (up to threefold), suggests saturation of the $\Delta^{9}$-desaturase system or a change in enzyme kinetics under these specific conditions. However, the desaturase index was not different for other fatty acid pairs in the desaturase index (Table 4). Another indication that the desaturase system is not likely to be limited by elevated concentrations of substrate or product is the investigation by Bauman et al. (2000a), which represented a unique situation wherein cows were fed and selected to produce CLA-enhanced milk fat; an increase was observed in both milk fat content of CLA ( $40.7 \mathrm{vs} .5 .3 \mathrm{mg} / \mathrm{g}$ of fatty acids) and the milk fat ratio of cis-9, trans- $11 \mathrm{CLA} /$ trans $-11 \mathrm{C}_{18: 1}$ (0.51 vs. $0.33)$. The second objective in the present study was to examine variation in the milk fat ratio of fatty acid pairs related to $\Delta^{9}$-desaturase. This enzyme is important in the maintenance of the fluidity of cellular membranes and milk fat (Parodi, 1982; Chilliard et al., 2000). There are four fatty acid pairs that represent a product/substrate relationship for $\Delta^{9}$-desaturase, and milk fat ra- 

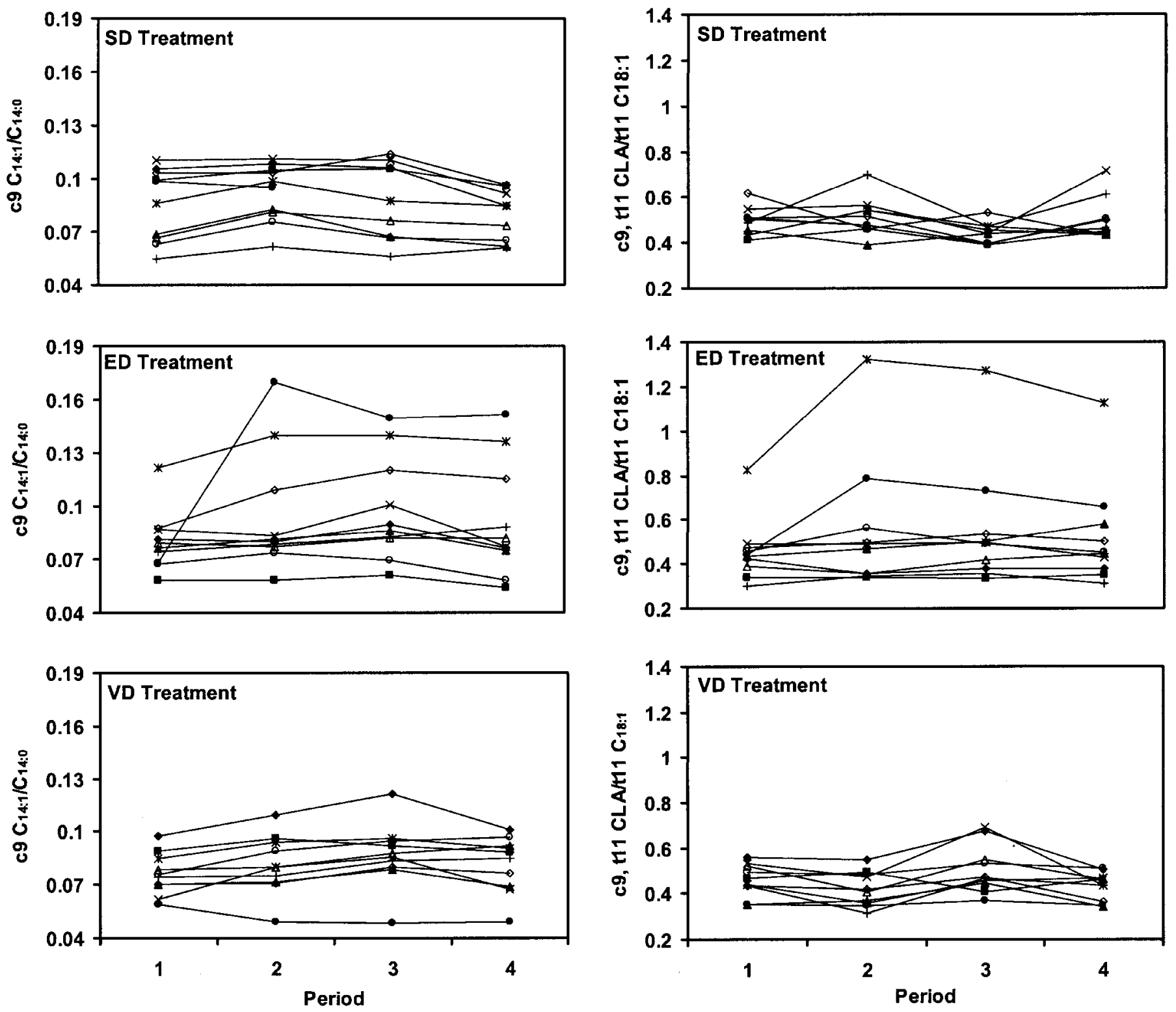

Figure 4. Desaturase index values for milk fat ratios of cis-9 $\mathrm{C}_{14: 1} / \mathrm{C}_{14: 0}$ and cis-9, trans-11 CLA/trans-11 $\mathrm{C}_{18: 1}$. Treatment groups included cows receiving a standard TMR diet (SD treatment), a diet including extruded full-fat soybeans (ED treatment), and a variable diet group (VD treatment) that alternated between diets at 3-wk intervals so that they received the SD treatment diet during periods 1 and 3 , and the ED treatment diet during periods 2 and 4 . Each symbol represents an individual cow $(\mathrm{n}=10$ cows per treatment) and each period value represents the average of the three weekly values for that period. SE for individual period means for the $\mathrm{C}_{14}$ desaturase index values averaged $0.0051,0.0051$ and 0.0054 for SD, ED, and VD, respectively; for the CLA desaturase index values, SE averaged 0.034, 0.034 and 0.036 for $\mathrm{SD}, \mathrm{ED}$, and VD, respectively.

tios for these pairs of fatty acids represent a proxy for $\Delta^{9}$-desaturase activity (Bauman et al., 2001). In the present study, all four of the fatty acid pairs were positively associated among individuals across all diets, with the correlation coefficients ranging from 0.48 to 0.78 (Table 5). In examining the individual hierarchy related to endogenous synthesis of CLA, the ratio of myristoleic acid to myristic acid (cis-9 $\left.\mathrm{C}_{14: 1} / \mathrm{C}_{14: 0}\right)$ may represent the best proxy for $\Delta^{9}$-desaturase activity in the mammary gland. Myristic acid originates almost exclusively via de novo synthesis within the mammary gland, and, as a consequence, all of the myristoleic acid present in milk fat would also be synthesized in the mammary gland by $\Delta^{9}$-desaturase. In contrast, fatty acid absorption from the digestive tract and mobilization of body fat reserves can account for a large and 
Table 5. Correlation coefficients between desaturase index values for the pairs of fatty acids representing product/substrate for $\Delta^{9}$-desaturase. ${ }^{1}$

\begin{tabular}{lllll}
\hline Fatty acid pair & $\mathrm{c} 9, \mathrm{t} 11 \mathrm{CLA} / \mathrm{t} 11 \mathrm{C}_{18: 1}$ & $\mathrm{c} \mathrm{C}_{14: 1} / \mathrm{C}_{14: 0}$ & $\mathrm{c} \mathrm{C}_{16: 1} / \mathrm{C}_{16: 0}$ & $\mathrm{c} \mathrm{C}_{18: 1} / \mathrm{C}_{18: 0}$ \\
\hline $\mathrm{c} 9, \mathrm{t} 11 \mathrm{CLA} / \mathrm{t} 11 \mathrm{C}_{18: 1}$ & 1 & 0.65 & 0.53 & 0.78 \\
$\mathrm{c9} \mathrm{C}_{14: 1} / \mathrm{C}_{14: 0}$ & & 1 & 0.48 & 0.66 \\
c9 $\mathrm{C}_{16: 1} / \mathrm{C}_{1: 0}$ & & & 1 & 0.66 \\
c9 $\mathrm{C}_{18: 1} / \mathrm{C}_{18: 0}$ & & 1 & 1 \\
\hline
\end{tabular}

${ }^{1}$ Twelve-week averages for each cow were used in correlation analysis ( $\mathrm{n}=30$ cows). All correlations were significant $(P<0.01)$.

variable proportion of palmitoleic, palmitic, oleic, stearic, and vaccenic acids as well as CLA, making these respective ratios less indicative of actual mammary activity of $\Delta^{9}$-desaturase.

This is the first study to extensively characterize individual variation in fatty acid pairs that represent a proxy for $\Delta^{9}$-desaturase activity. A range of approximately twofold in individual values was observed for all treatments for the ratios of cis- $9 \mathrm{C}_{14: 1} / \mathrm{C}_{14: 0}$ and cis9, trans-11 CLA/trans-11 $\mathrm{C}_{18: 1}$ (Figure 4). A similar range in individual variation was observed for cis-9 $\mathrm{C}_{16: 1} / \mathrm{C}_{16: 0}$ and cis-9 $\mathrm{C}_{18: 1} / \mathrm{C}_{18: 0}$ (data not presented). There was also a relatively consistent hierarchy in the desaturase index ratios over time for the ED and SD treatments (Figure 4). Even more illuminating was the VD treatment in which the individual hierarchy was maintained across time (Figure 4), even when cows were repeatedly switched between diets that caused the milk fat concentration of both cis-9, trans-11 CLA and trans $-11 \mathrm{C}_{18: 1}$ to vary approximately twofold (Table 3 ). The consistency of the individual hierarchy in desaturase index ratios suggests that a portion of the variation in milk fat content of CLA when cows are fed the same diet is related to individual differences in $\Delta^{9}$ desaturase activity. Presumably this would be represented by differences in the regulation of $\Delta^{9}$-desaturase gene expression, differences in primary or tertiary structure of the enzyme due to gene polymorphisms or posttranslational modifications or differences in downstream factors that would affect interaction between enzyme and substrate (e.g., phosphorylation). This is an obvious area for future research.

\section{CONCLUSIONS}

In the present study, substantial variation in milk fat CLA content between animals and across diets was observed, similar to previous studies. We also demonstrated that individual animals were quite consistent over time; the hierarchy of individual animals was maintained even when cows were switched between diets that give substantial differences in milk fat content of CLA. This suggests that rumen production of trans-11 $\mathrm{C}_{18: 1}$ and CLA varies among individuals on the same diet, and this would represent the basis for a portion of the individual variation in milk fat content of CLA. $\Delta^{9}$-desaturase is a key enzyme in the endogenous synthesis of CLA, and the milk fat ratios of fatty acid pairs that represent proxies for this enzyme also varied substantially even between animals on the same diet. This hierarchy among individuals was also relatively constant over the 12 -wk experiment, even when cows were alternated between dietary treatments. Thus, differences among individuals in $\Delta^{9}$-desaturase contribute to variation in milk fat content of CLA. Our results indicate that while diet is a major determinant of CLA in milk fat, some animals possess a greater potential to respond to a dietary treatment than others, and that these differences in response are consistent over time and across multiple dietary shifts.

\section{ACKNOWLEDGEMENTS}

The authors appreciate the assistance and contributions of D. Dwyer, M. Partridge, B. Corl, D. Ceurter, and M. Van Amburgh, as well as the support of Land O' Lakes, Inc.

\section{REFERENCES}

Bauman, D. E., D. M. Barbano, D. A. Dwyer, and J. M. Griinari. 2000a. Technical note: Production of butter with enhanced conjugated linoleic acid for use in biomedical studies with animal models. J. Dairy Sci. 83:2422-2425.

Bauman, D. E., L. H. Baumgard, B. A. Corl, and J. M. Griinari $2000 \mathrm{~b}$. Biosynthesis of conjugated linoleic acid in ruminants. Proc Am. Soc. Anim. Sci. 1999. Available at: http://www.asas.org/jas/ symposia/proceedings/0937.pdf.

Bauman, D. E., B. A. Corl, L. H. Baumgard, and J. M. Griinari. 2001 Conjugated linoleic acid (CLA) and the dairy cow. Pages 221-250 in Recent Advances in Animal Nutrition-2001, P. C. Garnsworthy and J. Wiseman, eds. Nottingham University Press, Nottingham, UK.

Chilliard, Y., A. Ferlay, R. M. Mansbridge, and R. M. Doreau. 2000. Ruminant milk fat plasticity: nutritional control of saturated, polyunsaturated, trans and conjugated fatty acids. Ann. Zootech. 49:181-205.

Choi, Y., Y. Kim, Y. Han, Y. Park, M. W. Pariza, and J. M. Ntambi. 2000 . The trans-10, cis-12 isomer of conjugated linoleic acid downregulates stearoyl-CoA desaturase 1 gene expression in 3T3-L1 adipocytes. J. Nutr. 130:1920-1924. 
Chouinard, P. Y., L. Corneau, D. M. Barbano, L. E. Metzger, and D. E. Bauman. 1999. Conjugated linoleic acids alter milk fatty acid composition and inhibit milk fat secretion in dairy cows. J. Nutr. 129:1579-1584.

Chouinard, P. Y., L. Corneau, W. R. Butler, Y. Chilliard, J. K Drackley, and D. E. Bauman. 2001. Effect of dietary lipid source on conjugated linoleic acid concentrations in milk fat. J. Dairy Sci. 84:680-690.

Christie, W. W. 1982. A simple procedure for rapid transmethylation of glycerolipids and cholesteryl esters. J. Lipid Res. 23:1072-1075.

Corl, B. A., L. H. Baumgard, D. A. Dwyer, J. M. Griinari, B. S. Phillips, and D. E. Bauman. 2001. The role of $\Delta^{9}$-desaturase in the production of cis-9, trans-11 CLA. J. Nutr. Biochem. 12:622-630.

Dhiman, T. R., G. R. Anand, L. D. Satter, and M. W. Pariza. 1999. Conjugated linoleic acid content of milk from cows fed different diets. J. Dairy Sci. 82:2146-2156.

Fox, D. G., C. J. Sniffen, J. D. O’Connor, J. B. Russell, and P. J. Van Soest. 1992. A net carbohydrate and protein system for evaluating cattle diets: III. Cattle requirements and diet adequacy. J. Anim. Sci. 70:3578-3596.

Griinari, J. M., and D. E. Bauman. 1999. Biosynthesis of conjugated linoleic acid and its incorporation into meat and milk in ruminants. Pages 180-200 in Advances in Conjugated Linoleic Acid Research. Vol. 1. M. P. Yurawecz, M. M. Mossoba, J. K. G. Kramer, M. W. Pariza, and G. J. Nelson, eds. AOCS Press, Champaign, IL.

Griinari, J. M., B. A. Corl, S. H. Lacy, P. Y. Chouinard, K. V. V. Nurmela, and D. E. Bauman. 2000. Conjugated linoleic acid is synthesized endogenously in lactating cows by $\Delta^{9}$-desaturase. J. Nutr. 130:2285-2291.

Hara, A., and N. S. Radin. 1978. Lipid extraction of tissues with a low-toxicity solvent. Anal. Biochem. 90:420-426.

Ip, C., S. Banni, E. Angioni, G. Carta, J. McGinley, H. J. Thompson, D. Barbano, and D. E. Bauman. 1999. Conjugated linoleic acidenriched butter fat alters mammary gland morphogenesis and reduces cancer risk in rats. J. Nutr. 129:2135-2142.

Jahreis, G., J. Fritsche, and H. Steinhart. 1997. Conjugated linoleic acid in milk fat: High variation depending on production system. Nutr. Res. 17:1479-1484.

Jiang, J., L. Bjoerck, R. Fondén, and M. Emanuelson. 1996. Occurrence of conjugated cis-9, trans-11-octadecadienoic acid in bovine milk: Effects of feed and dietary regimen. J. Dairy Sci. 79:438445 .

Kelly, M. L., J. R. Berry, D. A. Dwyer, J. M. Griinari, P. Y. Chouinard, M. E. Van Amburgh, and D. E. Bauman. 1998a. Dietary fatty acid sources affect conjugated linoleic acid concentrations in milk from lactating dairy cows. J. Nutr. 128:881-885.

Kelly, M. L., E. S. Kolver, D. E. Bauman, M. E. Van Amburgh, and L. D. Muller. 1998b. Effect of intake of pasture on concentrations of conjugated linoleic acid in milk of lactating cows. J. Dairy Sci. 81:1630-1636.

Lawless, F., J. J. Murphy, D. Harrington, R. Devery, and C. Stanton. 1998. Elevation of conjugated cis-9, trans-11-octadecadienoic acid in bovine milk because of dietary supplementation. J. Dairy Sci. 81:3259-3267.

Lawless, F., C. Stanton, P. L'Escop, R. Devery, P. Dillon, and J. J. Murphy. 1999. Influence of breed on bovine milk cis-9, trans-11 conjugated linoleic acid content. Livest. Prod. Sci. 62:43-49.

McGuire, M. A., and M. K. McGuire. 2000. Conjugated linoleic acid (CLA): A ruminant fatty acid with beneficial effects on human health. Proc Am. Soc. Anim. Sci. 1999. Available at: http://www. asas.org/jas/symposia/proceedings/0938.pdf.

National Research Council. 1989. Nutrient Requirements of Dairy Cattle. 6th rev. ed. Natl. Acad. Sci., Washington, DC.

Pariza, M. W., Y. Park, and M. E. Cook. 2001. The biologically active isomers of conjugated linoleic acid. Prog. Lipid Res. 40:283-298.

Parodi, P. W. 1982. Positional distribution of fatty acids in the triglyceride classes of milk fat. J. Dairy Res. 49:73-80.

Parodi, P. W. 1997. Cows' milk fat components as potential anticarcinogenic agents. J. Nutr. 127:1055-1060.

Ritzenthaler, K. L., M. K. McGuire, R. Falen, T. D. Shultz, N. Dasgupta, and M. A. McGuire. 2001. Estimation of conjugated linoleic acid intake by written dietary assessment methodologies underestimates actual intake evaluated by food duplicate methodology. J. Nutr. 131:1548-1554.

SAS Institute, Inc. 2000. Release 8.1. Cary, NC.

Sehat, N., J. K. G. Kramer, M. M. Mossoba, M. P. Yurawecz, J. A. G. Roach, K. Eulitz, K. M. Morehouse, and Y. Ku. 1998. Identification of conjugated linoleic acid isomers in cheese by gas chromatography, silver ion high performance liquid chromatography and mass spectral reconstructed ion profiles. Lipids 33:963-971.

Solomon, R., L. E. Chase, D. Ben-Ghedalia, and D. E. Bauman. 2000. The effect of nonstructural carbohydrate and addition of full fat extruded soybeans on the concentration of conjugated linoleic acid in the milk fat of dairy cows. J. Dairy Sci. 83:1322-1329.

Stanton, C., F. Lawless, G. Kjellmer, D. Harrington, R. Devery, J. F. Connolly, and J. Murphy. 1997. Dietary influences on bovine milk cis-9, trans-11 conjugated linoleic acid content. J. Food Sci. 62:1083-1086.

Whigham, L. D., M. E. Cook, and R. L. Atkinson. 2000. Conjugated linoleic acid: implications for human health. Pharmacol. Res. 42:503-510.

White, S. L., J. A. Bertrand, M. R. Wade, S. P. Washburn, J. T. Green, Jr., and T. C. Jenkins. 2001. Comparison of fatty acid content of milk from Jersey and Holstein cows consuming pasture or a total mixed ration. J. Dairy Sci. 84:2295-2301. 